\title{
On the Theoretical Value and Practical Significance of the Anti-Poverty Thought of Socialism with Chinese Characteristics
}

\author{
Shiming Liu \\ School of Marxism, University of Shanghai for Science and Technology, Shanghai, China \\ Email: shiming0303@163.com
}

How to cite this paper: Liu, S.M. (2018) On the Theoretical Value and Practical Significance of the Anti-Poverty Thought of Socialism with Chinese Characteristics. Open Journal of Social Sciences, 6, 141-155. https://doi.org/10.4236/jss.2018.611010

Received: October 22, 2018

Accepted: November 13, 2018

Published: November 16, 2018

Copyright $\odot 2018$ by author and Scientific Research Publishing Inc. This work is licensed under the Creative Commons Attribution International License (CC BY 4.0).

http://creativecommons.org/licenses/by/4.0/

\begin{abstract}
The anti-poverty thought of socialism with Chinese characteristics has important theoretical and practical significance. In terms of theoretical value, it continues to develop and innovate Marx's anti-poverty theory in China. In practical terms, it has successfully guided China's anti-poverty cause and made remarkable achievements, providing valuable experience for China and the world to continue to improve the conditions for people's survival and development.
\end{abstract}

\section{Keywords}

Anti-Poverty Thought of Socialism with Chinese Characteristics, Theoretical Value, Practical Significance, World Significance

\section{Introduction}

The formation and development of the anti-poverty thought of socialism with Chinese characteristics, as the latest theoretical achievement of the Chinization of Marx's anti-poverty theory, it embodies the leadership of the Communist Party of China led by Deng Xiaoping, Jiang Zemin, Hu Jintao and Xi Jinping. The collective wisdom of carrying out anti-poverty actions is a theoretical sublimation and experience summary of China's successful practice in combating poverty. It has profound theoretical value, practical guiding significance and world significance.

\section{What Is the Anti-Poverty Thought of Socialism with Chinese Characteristics?}

The anti-poverty thought of socialism with Chinese characteristics is the latest 
achievement of Marx's anti-poverty theory. It mainly includes Deng Xiaoping's anti-poverty thought, Jiang Zemin's anti-poverty thought, Hu Jintao's anti-poverty thought, Xi Jinping's anti-poverty thought and other major strategic thought.

\subsection{The Anti-Poverty Thought of the Leaders of the CCP Since the Reform and Opening up (1978-2012)}

First, Deng Xiaoping's anti-poverty thinking. In the anti-poverty thought system with Chinese characteristics, Deng Xiaoping's anti-poverty thought is the foundation stone of the anti-poverty thought of Chinese characteristics, and it is the inheritance and development of Marx's anti-poverty theory and Mao Zedong's anti-poverty thought. The reason why Deng Xiaoping's anti-poverty thought is the foundation stone is that it has created a systematic explanation and explanation of the anti-poverty road of socialism with Chinese characteristics, including the reinterpretation of the total root causes of poverty in China, and the scientific thesis on the relationship between poverty and socialism. And the choice of anti-poverty routes. Under the guidance of Deng Xiaoping's anti-poverty thought, 1978 became an important turning point in China's economic and social development. The Third Plenary Session of the 11th CPC Central Committee held this year opened the prelude to China's economic system reform. The main contents of China's economic system reform include adjustment of the national economic structure and reform of the rural economic system. Among them, the reform of the rural economic system has become a huge driving force for China's rural economic development. According to relevant statistics, from 1978 to 1985 , the total output value of Chinese township enterprises increased by an average of 20 billion annually. The rapid development of township and village enterprises has played a significant role in promoting agricultural development, rural economic development, and farmers' poverty alleviation. From 1978 to the end of 1985 , the per capita net income of farmers increased from 133.6 yuan to 397.6 yuan, an increase of $66.4 \%$, and the number of rural poor people decreased by 100 million. From 1986 to 1993, the proportion of rural poor in China accounted for the total rural population. $14.8 \%$ fell to $8.7 \%$ and the number of poor people fell by 50 million [1].

Second, Jiang Zemin's anti-poverty thinking. Since the Fourth Plenary Session of the 13th CPC Central Committee, the third-generation central leadership collective with Jiang Zemin at the core held high the great banner of Deng Xiaoping's theory of building socialism with Chinese characteristics, and adhered to China's major strategic concept of anti-poverty. Emphasizing the major political, economic and social significance of anti-poverty, it puts forward a series of strategic ideas such as anti-poverty is the party's purpose, anti-poverty is the essential attribute of socialism, and anti-poverty is an important embodiment of the development of China's human rights cause. Under the guidance of this idea, the "August 7th Poverty Alleviation Plan" was put forward. According to relevant 
statistics, from 1994 to 2000, the annual growth rate of China's per capita GDP exceeded $12 \%$, and the per capita net income of rural residents increased from 1221 yuan to 2253 yuan, an increase of $45.8 \%$. High-speed economic growth has provided a powerful impetus to rural anti-poverty, with the number of poor people reduced by more than 37 million [1].

Third, Hu Jintao's anti-poverty thinking. Since the 16th National Congress of the Communist Party of China, the fourth-generation central leadership group with $\mathrm{Hu}$ Jintao as the core has put forward the scientific development concept and provided strong ideas for promoting sound and rapid economic and social development. Hu Jintao's anti-poverty thinking includes the people-oriented anti-poverty concept, the anti-poverty path to build a harmonious society, and the anti-poverty goal of building a comprehensive well-off society. Under the guidance of Hu Jintao's anti-poverty thinking, the Party Central Committee adjusted the anti-poverty strategy according to the new characteristics of poverty and the goal of building a well-off society in an all-round way. First, we must adhere to the poverty alleviation and development strategy, through the development of breeding and breeding industries in poverty-stricken areas, the promotion of agricultural industrialization, the improvement of basic production and living conditions in poverty-stricken areas, and the improvement of the scientific and technological cultural quality of the people in poverty-stricken areas. The second is to improve the poverty alleviation targeting mechanism and move the poverty alleviation targeting unit to the village level, that is, "project of whole village promotion in poverty alleviation". From 2001 to 2010, China completed the project of whole village promotion in poverty alleviation task of 19000 poor villages. At the same time, the number of rural poor in China has decreased by more than 60 million, and the nation's anti-poverty has made tremendous progress [1].

\subsection{Xi Jinping's Anti-Poverty Thought Since the 18th National Congress of the Communist Party of China (2012-Present)}

Since the 18th National Congress of the Communist Party of China, the leadership of the Party Central Committee with General Secretary Xi Jinping as the core has focused on the fundamental issue of "what kind of national governance is to be achieved, how to govern the country", and combined with the situation of poverty change in the new era, Anti-poverty thinking based on the core and endogenous poverty alleviation.

First, anti-poverty is the essential requirement of socialism.

Since the 18th National Congress of the Communist Party of China, Xi Jinping has repeatedly visited the poorest areas of the country to investigate poverty management. He believes that poverty is not socialism. If poverty-stricken areas are chronically poor, face long-term changes, and people's lives cannot be significantly improved for a long time, then they do not reflect the superiority of China's socialist system. It is not socialism [2]. When he was inspected in Hebei 
Province, he also pointed out that poverty eradication, improvement of people's livelihood and common prosperity are the essential requirements of socialism [3]. It can be seen that the Party Central Committee with Xi Jinping as the core will proceed from the essence of socialism and will fight against poverty. The work has been raised to the height of the national strategy, which fully reflects the continuous deepening of the understanding of the laws of socialist construction by the Chinese communists in the practice of anti-poverty.

Second, anti-poverty is an important mission of the Communist Party of China.

Anti-poverty is the solemn commitment and goal of the Chinese Communist Party to the people and to history. Xi Jinping clearly pointed out that doing a good job in poverty alleviation and development, supporting the poor to get rid of poverty, helping them solve problems and making development results more fair and fair to the people is an important manifestation of our party's fundamental purpose of serving the people wholeheartedly and is also a major responsibility of the party and the government [4]. The party's central leadership group with $\mathrm{Xi}$ Jinping as the core, standing at the forefront of the development of the times and history, and making strategic judgments on the party's status and historical mission, will undoubtedly enhance the party's mission consciousness and spirit, and resolutely win the fight against poverty. The tough battle provides ideological protection.

Third, the external motivation for combating poverty is social assistance.

Since the 18th National Congress of the Communist Party of China, Xi Jinping has repeatedly emphasized the importance of social assistance on different occasions and regarded it as an "external driving force" against poverty. Xi Jinping clearly pointed out that to improve the coordination between the East and the West and the fixed-point poverty alleviation mechanism of the party and government organs, all departments must actively complete the task of poverty alleviation undertaken by the central region. To help, state-owned enterprises must undertake more poverty alleviation and development tasks [5]. In 2017, when Xi Jinping made a report on the 19th National Congress of the Communist Party of China, he once again stressed that resolutely winning the battle against poverty, it must be "all the whole society must take the initiative to undertake this Joint responsibility." [6]. From the height of anti-poverty and strategy, Xi Jinping profoundly clarified the status, objectives, tasks and basic requirements of social assistance, and answered in depth the major issues of China's anti-poverty content and ways in the new era. Social forces participate in anti-poverty to provide basic compliance.

Fourth, the internal driving force of anti-poverty is education poverty alleviation.

Regarding the issue of poverty education, $\mathrm{Xi}$ Jinping has always paid attention to it for a long time, and put forward a series of ideas and viewpoints to solve poverty, and gradually developed his own education and poverty alleviation ideas. 
In the early 1980s, Xi Jinping mentioned in the book "UP AND OUT OF POVERTY" that education poverty alleviation. The proposal of this poverty alleviation strategy fully reflects the high level of understanding and value of the role of education in the fight against poverty. Since the 18th National Congress of the Communist Party of China, Xi Jinping's series of important speeches since the 18th National Congress of the Communist Party of China have been consistent with the concept of education and poverty alleviation mentioned in the book "UP AND OUT OF POVERTY". Specifically, it helps the poor to ideologically dilute the sense of poverty. Then, through education to help the poor, help the poor to focus on improving the overall quality of poverty alleviation. This is the specific application of "giving people a fish is not as good as giving people a fish". Only in this way can the poor population truly get rid of poverty.

Fifth, the fundamental method of combating poverty is targeted poverty allaviation.

On November 3, 2013, when Xi Jinping went to the Tujia-Miao Autonomous Prefecture of Xiangxi, central China's Hunan Province, for an inspection. He clearly pointed out that poverty alleviation should be realistic and appropriate, and tailored to local conditions. To ensure poverty alleviation, avoid shouting slogans, and do not set high goals. This is the first time Xi Jinping proposed. The concept of targeted poverty all aviation provides new ideas for China's anti-poverty in the new era.

The concept of targeted poverty all aviation is an important part of Xi Jinping's anti-poverty thinking, and it is also the most crucial point. Xi Jinping profoundly explained the concept of precision poverty alleviation. He clearly pointed out that poverty alleviation and development is more precise, more precise, and the success or failure lies in precision. All localities must be precise in supporting objects, precise project arrangement, accurate use of funds, accurate measures to the home, Because the village party (first secretary) is accurate, the effect of poverty alleviation is accurate, and the method is effective, and the real effect is seen [7]. In summary, that is, "six precision." In November 2015, Xi Jinping emphasized in the Central Poverty Alleviation and Development Work Conference that it is necessary to solve the problem of "how to help" and propose the implementation of "five batches" according to the specific conditions of poor areas and poor people. The "five batches" include the development of production and poverty alleviation, the easy relocation of poverty alleviation, the ecological compensation for poverty alleviation, the development of education for poverty, and the social security. The "six precisions" and "five batches" are the signs that Xi Jinping's concept of targeted poverty all aviation has really developed and matured.

Sixth, the real goal of anti-poverty is the well-off in poor areas.

Building a well-off society in an all-round way is a phased goal of realizing the Chinese dream. It has an important historical position in realizing the Chinese dream and has become the theme of the times when the Chinese Communist Party leads the people of the whole country to work together. The so-called Chi- 
nese dream is aimed at realizing the great practice of the trinity of the people's happiness, the country's prosperity, and the national rejuvenation. To achieve a comprehensive well-off society is the primary goal of realizing the Chinese dream. Since the 18th National Congress of the Communist Party of China, the leadership of the Party Central Committee with Xi Jinping as the core has put forward many new ideas and new ideas around the "building a well-off society in an all-round way" and scientifically answered a series of strategic contents of the Chinese Communist Party's anti-poverty in the new era.

$\mathrm{Xi}$ Jinping has repeatedly stated that there is a dialectical relationship between building a well-off society in an all-round way and fighting poverty. On December 29, 2012, when Xi Jinping inspected poverty alleviation and development work in Zhangping, Hebei Province, he clearly pointed out that China's people's living standards have changed greatly in the past 30 years of reform and opening up. At the same time, as China is still in the primary stage of socialism, there are still many difficult people. The most difficult and arduous task in building a well-off society in an all-round way is in rural areas, especially in poor areas. Without a well-off society in rural areas, especially if there is no well-off in poor areas, there will be no comprehensive well-off society [3]. On October 29, 2015, $\mathrm{Xi}$ Jinping made a speech at the second plenary session of the Fifth Plenary Session of the 18th CPC Central Committee, he clearly pointed out that poverty alleviation in rural areas is the most prominent shortcoming. Although comprehensive well-off is not the same well-off for everyone, if the existing living standards of more than 70 million rural poor people have not improved significantly, the overall well-off society cannot be convinced [8].

It can be seen that Xi Jinping has continuously enriched the strategic layout and accurately grasped the strategic positioning according to the new situation faced in the decisive stage of building a well-off society in an all-round way, and always took poverty-stricken people out of poverty as the bottom line task and landmark indicator for building a well-off society in an all-round way. It can be said that this is Xi Jinping's new understanding and scientific judgment on building a well-off society in an all-round way. In order to broaden the path of anti-poverty, the Chinese Communist Party shoulders the heavy responsibility of uniting and leading the people to build a well-off society in an all-round way, promote socialist modernization, and realize the great rejuvenation of the Chinese nation. "Provide theoretical compliance and action guidelines.

In general, since the 18th National Party Congress, Decisive progress has been made in the fight against poverty: more than 60 million people have been lifted out of poverty, and the poverty headcount ratio has dropped from $10.2 \%$ to less than $4 \%$. All-round progress has been made in the development of education, with remarkable advances made in the central and western regions and in rural areas. Employment has registered steady growth, with an average of over 13 million urban jobs created each year. Social governance systems have been improved; law and order has been maintained; and national security has been fully enhanced [6]. 


\section{The Theoretical Value of the Anti-Poverty Thought of Socialism with Chinese Characteristics}

\subsection{Developing the Scientific Connotation of Marxist Anti-Poverty Theory}

The anti-poverty thinking centered on the people has enriched and developed the theory of all-round development of Marxists. The so-called all-round development of man, Marx pointed out that replacement of the old bourgeois society with class and class opposition will be such a consortium, where the free development of everyone is the condition for the free development of all people [9]. Since the reform and opening up, the Communist Party of China has raised the all-round development of people to a new strategic height, unswervingly pursues the anti-poverty road that puts the interests of the people first, and always takes the improvement of people's lives and the improvement of people's well-being as the starting point and the foothold. Look for development momentum among the people, rely on the people to promote development, and make development work for the people. Practice has proved that adhering to the people-centered development thinking, injecting the most fresh power into the anti-poverty cause, and truly starting from the interests of the people's most concerned, so that the sense of poverty is growing. It profoundly reveals the essential attributes of socialism with Chinese characteristics and also gives the era connotation of the theory of all-round development of Marxists.

The anti-poverty thinking centered on economic construction has enriched and developed the Marxist theory of productive forces development. The so-called economic construction as the center refers to the work of the Chinese Communist Party in the center of the basic line of the primary stage of socialism and the development of socialism with Chinese characteristics. In essence, economic development benefits the entire society and benefits more people. In China, development is first and foremost the development of the economy, with the aim of realizing the Chinese dream of the great rejuvenation of the Chinese nation. The so-called Chinese dream is also a socialist dream, which is the goal of realizing the building of a well-off society in an all-round way and building a prosperous, strong, democratic, civilized and harmonious socialist modern country. The fundamental task of socialism is to develop productive forces. Therefore, the key to realizing the Chinese dream is to persist in taking economic construction as the center and improve productivity. Adhere to economic construction as the central task, comprehensively grasp the fundamental requirements of the people as the center, and the results of development are shared by the people. This is the deepening of the Chinese Communist Party's understanding of the interests of the people and the further expansion of practice. This is the core and essence of the anti-poverty thinking of socialism with Chinese characteristics, and it is also a model for the innovation of Marxist productivity development.

The anti-poverty thinking based on institutional construction has enriched 
and developed the Marxist institutional development theory. The so-called socialist system with Chinese characteristics is the product of combining the basic principles of Marxism with China's concrete reality under the leadership of the Communist Party of China and is the fundamental guarantee for the victory of socialist modernization. Since the reform and opening up, our party has attached great importance to the system construction. By continuously improving and developing the socialist system with Chinese characteristics, it has promoted the development of China's anti-poverty cause. From a certain level of significance, the continuous development of anti-poverty thinking based on institutional construction is also progressing in the process of Chinization of Marxist institutional development theory.

\subsection{Consolidating the Guiding Position of Marxist Anti-Poverty Theory}

Looking back on the anti-poverty process in the past forty years, especially since the 18th National Congress of the Communist Party of China, more than 60 million people have been lifted out of poverty, and the poverty headcount ratio has dropped from $10.2 \%$ to less than $4 \%$ [6]. Practice has repeatedly proved that the key to the success of China's anti-poverty cause is that the Chinese Communist Party has unswervingly adhered to the basic principles of Marxism, constantly carried out theoretical innovations, promoted the Chinization of Marxism, and made Marxism more distinctive in Chinese characteristics, characteristics of the times and culture. The characteristics have produced the anti-poverty thought of socialism with Chinese characteristics, and used it to guide practice and promote the development of anti-poverty cause.

As Xi Jinping pointed out that Marxism is our fundamental guiding thought for building a party. If we turn away from or abandon Marxism, our party will lose its soul and lose its direction. On the fundamental issue of upholding the guiding position of Marxism, we must be firm. It must not be shaken at any time and under any circumstances [10]. It can be seen that upholding and consolidating the guiding position of Marxism is the fundamental ideological guarantee for the unity of the party and the people and always moving in the right direction.

\section{The Practical Significance of the Anti-Poverty Thought of Socialism with Chinese Characteristics}

\subsection{Pointing out the Correct Direction for China to Launch a New Journey against Poverty}

Although China's 40-year anti-poverty process has gone through hardships, overall, achievements have undoubtedly been outstanding, and the road direction is undoubtedly correct. The fundamental reason lies in the correctness of guiding thought and uses its thoughts as a scientific guide for practice. The Marxist anti-poverty theory points out the direction for the development of China's anti-poverty cause. Mao Zedong's anti-poverty thinking is more in line 
with the basic national conditions and starts the anti-poverty cause from reality. The exploration of socialist anti-poverty thinking with Chinese characteristics has raised the anti-poverty cause to a new strategic height and escorted the successful socialist anti-poverty road with Chinese characteristics.

The anti-poverty thought of socialism with Chinese characteristics leads the way forward, shows our party's understanding of the development law of poverty and anti-poverty issues, has reached a new strategic height, and opened up a new realm of Marxist anti-poverty theory development. This is because the anti-poverty thinking of socialism with Chinese characteristics is the spirit of the times that advances with the times. It is the Marxist anti-poverty theory that is oriented toward the 21 st century and is the development goal and grand blueprint for guiding China to achieve the new stage of anti-poverty. A scientific guide to struggle.

\subsection{Providing a Scientific Method for China to Meet the New Challenges of Anti-Poverty}

Marxism believes that in the practice of inquiry, we must adhere to the scientific attitude of seeking truth from facts. The anti-poverty thought of socialism with Chinese characteristics is the latest achievement of the Chinization of Marxist anti-poverty theory. From inheritance to innovation and development, its scientificity runs through the whole theoretical development process and provides a scientific methodology for China's anti-poverty practice.

Theory combines practical science. The Chinese Communist Party has always attached great importance to the profound connotation of the use of Chinese traditional culture, and has innovated and transformed a series of concepts that emphasize the people, innovation, and the pursuit of the same, and applied it scientifically and rationally to the anti-poverty thinking of socialism with Chinese characteristics. A series of new theoretical and new strategies, such as "common prosperity", "harmonious society" and "people-centered development thinking”, provide theoretical guidance and practical guidance for China's anti-poverty practice. It can be seen that the Communist Party of China organically combines Marx's anti-poverty theory with China's concrete reality, which gives the Marxist theory a new vitality, and makes its theory more scientific and operative in guiding China's anti-poverty practice.

Theory guides the scientific nature of practice. Marxism believes that the theory comes from practice, through the test of practice, and provides scientific guidance for the practice. This is the fundamental principle that combines theory with practice. The historical process of China's anti-poverty is a historical process of adhering to this principle. Moreover, practice has proved that since China entered a new era, more than 60 million people have been lifted out of poverty, and the poverty headcount ratio has dropped from $10.2 \%$ to less than $4 \%$ [6]. This is the historical achievement of adhering to Xi Jinping's new era of socialism with Chinese characteristics, and it is the inevitable result of attaching great importance to theoretical guidance and practice. In this regard, Xi Jinping 
clearly pointed out that we must attach great importance to the role of theory, enhance theoretical self-confidence and strategic strength, and firmly adhere to the correct theory that has been repeatedly practiced and compared [11]. In short, develop science on the basis of practice. Theory, and using its theory to guide new practices, will be the key to ensuring the success of practice. It will provide a scientific method for the development of social undertakings in our country.

\section{The World Significance of the Anti-Poverty Thought of Socialism with Chinese Characteristics}

\subsection{Promoting the Development of the World's Anti-Poverty Cause}

The eradication of poverty has always been a worldwide problem. How to formulate effective solutions is a major test of the ability of the country to govern. Most countries in the world face the challenge of overcoming poverty. Due to differences in national conditions, countries are striving to explore anti-poverty models that suit their own characteristics. The typical foreign countries have the "development pole" model represented by Brazil and the "social insurance" model represented by the United States. Compared with these countries, China has successfully explored a set of anti-poverty models with its own characteristics, which has enabled China to achieve remarkable achievements in reducing poverty and improving people's living standards, which has aroused widespread concern and high praise from the international community.

According to relevant statistics, in 1981, the incidence of poverty in China was $88.32 \%$, which was $46.41 \%$ higher than the incidence of world poverty in the same period. However, since the 1990s, the number of poor people in China has continued to decline rapidly. Until 2011, the incidence of poverty in China has dropped to around 10\%, which means that China's poor population accounts for only one-tenth of the world's poor. From 1981 to 2013, the number of poor people in China decreased by 853 million people. The rate of poverty reduction exceeded the world level of the same period by $37 \%$, and the contribution rate to the world was as high as $75.69 \%$ [12]. The World Bank thinks that China has lifted so many people out of poverty in such a short period of time, which is unprecedented for all mankind. Without China's poverty alleviation efforts, the number of poor people in developing countries will not decrease in the last two decades of the twentieth century [13]. Indeed, China has been able to achieve such a huge historical achievement in a short period of time and created a veritable "Chinese miracle" in the history of world anti-poverty. In a certain sense, China's anti-poverty can provide valuable experience for China to continue to improve the conditions for the survival and development of the people in the new stage. It will also provide a valuable reference for overcoming poverty in other low-income regions of the world and make a theoretical development for the world's anti-poverty. Actively contribute. In the report of the 19th National Congress of the Communist Party of China, Xi Jinping clearly pointed out that 
the road of socialism with Chinese characteristics, theories, systems, and cultures are constantly developing, expanding the way for developing countries to modernize, and giving the world those who wish to accelerate development and hope to maintain their independence. The country and the nation have provided new choices and contributed Chinese wisdom and Chinese solutions to solving human problems.

The so-called China Wisdom and China Program refers to the experience summarization and theoretical sublimation based on China's basic national conditions and socialist construction, and is the result of a general understanding of the development of human society. It is not only based on the understanding of China's problems and Chinese experience, but also a set of systematic and scientific governance systems established on the strategic height of human development and the development of its development. At such a strategic level, it will not only change China, but also profoundly affect the world and have far-reaching world significance.

First, China's anti-poverty has accelerated the global poverty reduction process and made a major contribution to the world's poverty reduction cause. By 2020, China will eliminate the goal of all absolute poverty population under the current standards, so as to achieve a comprehensive well-off society. This great goal is highly consistent with the development goal set by the United Nations General Assembly on the UN 2030 Agenda for Sustainable Development to eliminate extreme poverty and bring everyone's life to basic standards by 2030, which means that China will take the lead. Complete the poverty reduction goals set by the United Nations and become the largest contributor to the world's poverty reduction cause.

Second, China's anti-poverty model has important reference value for overcoming poverty in other low-income regions of the world. At the international level, according to the 2016 Annual Report on Development and Globalization, Poverty alleviation is the most prominent in East Asia and the Pacific, where the proportion of people living in extreme poverty has fallen from over $80 \%$ in the 1980 s to less than $8 \%$ today. The report also said that although the number of extremely poor people has fallen sharply worldwide, the pace of poverty alleviation is uneven in different countries and regions. There are still 836 million people living in extreme poverty and $80 \%$ living in this region. The population continues to survive on less than $\$ 1.25$ a day. It can be seen that while the world economy has achieved rapid development and humanity has made remarkable achievements in combating poverty, poverty is still a serious reality in the development of the world today. In this context, China's anti-poverty cause has achieved such great success, which undoubtedly shows that China's anti-poverty experience has world-class performance. It fully demonstrates China's ability to provide China's wisdom and experience for the cause of human anti-poverty. It also shows that China's anti-poverty model is a summary of the Chinese people's experience in the anti-poverty process and theoretical sublimation. It has been formed through numerous tests of practice. A systematic and scientific gover- 
nance system that provides valuable experience in overcoming poverty in other low-income areas of the world. Therefore, developing countries must follow the path of poverty alleviation and development that is in line with their national conditions and effectively benefit the poor. Adhere to independence and self-reliance as the fundamental starting point for development, let the anti-poverty cause run through the whole process of social development, and strive to increase the speed of economic growth so that the fruits of economic development benefit the poor.

\subsection{Highlighting the Superiority of the Socialist System}

Since the reform and opening up, China has made great achievements in combating poverty, highlighting the superiority of the socialist system with Chinese characteristics.

First, the strong leadership of the party organization is conducive to mobilizing the enthusiasm, initiative and creativity of the broad masses of the people and all aspects of society. Upholding the party's leadership as the most essential feature of socialism with Chinese characteristics is not only a profound revelation of the institutional nature of socialism with Chinese characteristics, but also a high-level summary of the development of anti-poverty undertakings since the reform and opening up. Practice has proved that a strong leadership group of the party organization can give full play to the core leadership role of persisting in taking the people as the center, grasping the overall situation, brainstorming, consolidating the strength of all parties in the country, and fully concentrating on the construction of the socialist cause.

Second, having an efficient decision-making mechanism is conducive to ensuring the scientific and effective decision-making process. The so-called efficient decision-making mechanism, in the words of Deng Xiaoping, is that "the socialist country has one of the greatest advantages. It is to do one thing, and to make a decision. Once a resolution is made, it will be executed immediately and will not be involved." [14]. Practice has proved that Under the background of this efficient decision-making mechanism, the Communist Party of China can use the state power to quickly integrate the favorable resources of the whole society, accelerate the process of socialist modernization, and achieve remarkable results.

Third, persisting in unified leadership is conducive to concentrating our efforts on major issues. Deng Xiaoping believes that compared with capitalism, socialism has the advantage of persisting in unified leadership, concentrating its strength and ensuring its emphasis [14]. As the ruling party, the Communist Party of China plays a leading role in the cause of socialism with Chinese characteristics. In the overall decision-making system, party committees at all levels can achieve an organic combination of social manpower, material resources and financial resources through overall planning and coordination, so as to ensure that decision-making can be promoted and carried out effectively.

Fourth, vigorously emancipating and developing productive forces will help 
provide a solid material foundation for promoting comprehensive economic and social development. Looking back on the 40 years of reform and opening up, China's economy has maintained rapid and steady growth, and its annual growth rate is faster than any other country in the world. The so-called economic growth is the fundamental manifestation of the liberation and development of productive forces. As a socialist country, China can indeed create higher productivity than capitalist countries. Moreover, practice has proved that while maintaining rapid and steady economic growth. China has also provided a solid material foundation for socialist modernization, and the development of the anti-poverty cause has benefited from such development results.

Fifth, adhering to the people-centered development thought is conducive to maintaining and promoting social fairness and justice and achieving common prosperity for all people. Marx pointed out the alienation of human beings caused by capital in promoting the development of productive forces. The formulation of the people-centered development thought, based on the development of subjectivity, solves the problem of the confrontation between capital and labor, and is the inevitable result of promoting the organic unity of productivity and production relations. It profoundly clarifies the fundamental problem of developing for whom, who depends on development, and who shares development results. It is to always develop the people, rely on the people, benefit the people, and always regard the realization, maintenance, and development of the interests of the people as the starting point and end point of anti-poverty.

Sixth, the working model of advancing with the times is conducive to effectively coping with various risk challenges on the road ahead. The power of Marxism lies in truth and science, and its vitality lies in theoretical innovation that is never exhausted. As the latest theoretical achievement of Marxism in China, it is inevitable to inherit the theoretical quality of Marxism advancing with the times. It is a thought that constantly explores and innovates in practice and continuously promotes innovation in all aspects through theoretical innovation. In this process, the Communist Party of China can actively adapt to the development requirements of the new situation, and on this basis, put forward the correct line, guidelines and policies in line with China's national conditions, and achieved remarkable results. In the final analysis, the Chinese Communist Party has the theoretical quality of advancing with the times. This theoretical quality is also the essential characteristic of the anti-poverty thinking of socialism with Chinese characteristics. It highlights that it is a historical product formed along with the development of the times and the situation. Moreover, the Communist Party of China persists in developing the anti-poverty thinking of socialism with Chinese characteristics in practice, and consciously promotes its theoretical innovation with its firm practical beliefs, making it more innovative, thus providing a scientific basis for China's anti-poverty practice.

To sum up, this is the outstanding stability of the Chinese ruling party and gives the people a consistent anti-poverty strategy. It fully embodies our party's strong determination and confidence in getting rid of poverty and achieving 
common prosperity. At the same time, it profoundly reflects that this is a development path that our people highly consciously choose, highlighting the superiority of socialism and strongly demonstrating the strong socialist society. Vitality greatly enriches the theory of scientific socialism and provides a paradigm for the development of a socialist country.

\section{Conclusions}

To sum up, since the reform and opening up, China has formed and integrated into an anti-poverty ideology with reasonable structure and great success in guiding practice, that is, the anti-poverty thought of socialism with Chinese characteristics. It can be said that the formation and development of the anti-poverty thought of socialism with Chinese characteristics fully reflects the organic combination of China's excellent traditional culture and the development of the times. It has a distinct theoretical character. It not only provides scientific guidance for anti-poverty in China and the world, but also promotes the deepening and development of Marx's anti-poverty theory in practice, and plays a vital role in the formation of the Chinese-style Marx anti-poverty theory.

At present, China's poverty alleviation has entered the sprint stage, and the tasks and challenges facing poverty are even more arduous. Therefore, how to further improve and improve the long-term mechanism for stabilizing poverty alleviation, fundamentally solve the problem of "getting out of poverty" and "returning to poverty"; how to better promote the poverty alleviation and development strategy of diversified and coordinated development, and create complementary advantages, long-term cooperation, and focus on poverty alleviation Achieve a win-win situation; how to let all people share the fruits of reform, meet the basic needs of the poor people to pursue a happy life, and so on. These are all outstanding problems that the Chinese Communists urgently need to solve in the anti-poverty era in the new era. To solve the problems of the real society, we need to correctly grasp the guidance of ideological theory. Therefore, to solve the problem of poverty in China in the new era, we need to further understand the essence of the anti-poverty thought of socialism with Chinese characteristics, grasp the core essence of its thinking, and truly unify our thoughts and actions into new practice before we can work hard to create China Characteristic new socialist anti-poverty cause.

\section{Conflicts of Interest}

The author declares no conflicts of interest regarding the publication of this paper.

\section{References}

[1] The Data Mainly Comes from the Chinese Statistical Yearbook.

[2] Xi, J.P. (2016) Xi Jinping's Excerpts on the Comprehensive Construction of a Well-Off Society. Central Literature Publishing House, Beijing, 25.

[3] Xi, J.P. (2014) Xi Jinping: The Governance of China (Volume 1). Foreign Languages 
Press, Beijing, 189.

[4] (2014) Xi Jinping's "Poverty Alleviation View": Adapting to Local Conditions "Really Helping the Poor, Helping the Poor". People's Daily, 10.

[5] (2015) Xi Jinping's Speech at the Main Responsible Comrades' Meeting of Some Provincial and Municipal Party Committees in Guizhou. People’s Daily, 6.

[6] Xi, J.P. (2017) Secure a Decisive Victory in Building a Moderately Prosperous Society in All Respects and Strive for the Great Success of Socialism with Chinese Characteristics for a New Era-Delivered at the 19th National Congress of the Communist Party of China. People's Daily, 2017-10-28.

[7] (2015) Xi Jinping Held the Symposium of the Main Responsible Comrades of Some Provincial and Municipal Party Committees in Guizhou. People's Daily, 6.

[8] Xi, J.P. (2017) Xi Jinping: The Governance of China (Volume 2). Foreign Languages Press, Beijing, 79-80.

[9] Marx and Engels (2014) Communist Manifesto. People's Publishing House, Beijing, 51.

[10] Xi Jinping's Speech at the Celebration of the 95th Anniversary of the Founding of the Communist Party of China. People's Daily, 2016-7-11.

[11] Xi Jinping Presided over the 20th Collective Study Speech of the Political Bureau of the CPC Central Committee. People's Daily, 2015-01-25.

[12] Liu, S.M. (2018) The Development Process, Innovation and Effectiveness of Poverty Reduction in China. Journal of Shandong Agricultural University (Social Science Edition), 2.

[13] On October 29, 2015 China-From Poor Areas to Poor People: China's Evolving Poverty Reduction Agenda-An Assessment of Poverty and Inequality in China. World Bank, 2009.

[14] Deng, X.P. (1993) Selected Works of Deng Xiaoping (Volume 3). People's Publishing House, Beijing, 16-240. 